\title{
NASIONALISME DALAM KEARIFAN LOKAL PADA PERKAWINAN ADAT SUKU DAYAK KEBAHAN DI DESA MAPAN JAYA
}

\author{
Mardawani, Muisan Jaya
}

STKIP Persada Khatulistiwa Sintang, Pendidikan Pancasila dan Kewarganegaraan, Sintang

Email: mardawani113@yahoo.co.id, Muisanjaya@gmail.com

\begin{abstract}
This research examined about nationalism in local knowledge in a ceremony marriage customsof Dayak Kebahan in Mapan Jaya Village.The purpose of this research is to examine more deeply about nationalism that is found in traditional marriage ceremonies of Dayak Kebahan in Mapan Jaya Village. The sense of nationalism that is in a ceremony and customs in indonesia fixed in their shells as an effort to preservation of the cultural of existing local wisdom. The methods used in this research is descriptive qualitative and the form of phenomenological study. The technique of data collection used the technique ofobservation, interview, and documentation.The result of this researchshowing that: 1 ) there have been instances of the value of nationalism on traditional marriage ceremony of Dayak Kebahan in Mapan Jaya Village , 2 ) in modern era the traditional marriage customof Dayak Kebahan in Mapan Jaya Village is still has been undertaken in the many members of the community, especially for those that are capable economically, and 3 ) there are the efforts carried out to preserve without abandoning the local wisdom marriage customs of Dayak Kebahan in Mapan Jaya Village and gives out some kind of special policies for those who cannot afford the part of traditional marriage custom that do not have to paid. Keywords: nationalism, local wisdom, indigenous marriage.
\end{abstract}


Jurnal PEKAN Vol. 4 No. 1 Edisi April 2019 Mardawani,Muisan.J,Nasionalisme...75

\begin{abstract}
Abstrak
Penelitian ini mengkaji tentang Nasionalisme dalam Kearifan Lokal pada Upacara Perkawinan Adat Suku Dayak Kebahan di Desa Mapan Jaya. Tujuan dari penelitian adalah ingin mengkaji lebih mendalam tentang nasionalisme yang terdapat pada upacara adat perekawinan suku Dayak Kebahan di Desa Mapan Jaya. Seharusnya rasa nasionalisme yang ada pada upacara dan adat istiadat di Indonesia tetap terpelihara sebagai upaya pelestarian budaya kearifan lokal yang ada. Metode yang digunakan dalam penelitian ini deskriptif kualitatif dan bentuk penelitian studi fenomenologis. Teknik pengumpulan data menggunakan teknik observasi, wawancara, dan dokumentasi. Hasil penelitian ini menunjukan bahwa: 1) terdapat nilai-nilai nasionalisme pada uapacara perkawinan adat suku Dayak Kebahan di Desa Mapan Jaya, 2) Di era modern saat ini upacara perkawinan adat Suku Dayak Kebahan di Desa Mapan Jaya masih dilaksanakan oleh sebagian masyarakat, terutama mereka yang mampu secara ekonomi, dan 3) Terdapat upaya yang dilakukan untuk melestarikan kearifan lokal perkawinan adat yaitu dengan mengajak seluruh masyarakat Desa Mapan Jaya untuk melaksanakan dan tidak meninggalkan perkawinan adat yang ada di Desa Mapan Jaya dan memberikan semacam kebijakan khusus bahwa bagi yang tidak mampu ada bagian dari adat yang tidak perlu dibayar.
\end{abstract}

Kata Kunci: Nasionalisme, Kearifan Lokal, Perkawinan Adat. 


\section{A. Pendahuluan}

Indonesia merupakan

negara yang memiliki penduduk terbesar ke-empat di dunia. Dengan populasi penduduk yang cukup besar Indonesia juga dihuni oleh berbagai suku bangsa sehingga dipandang sebagai masyarakat yang multikultur. banyak adat istiadat dan bahasa yang digunakan disamping yang bersifat nasional sebagai kearifan lokal. Dalam kondisi yang demikian tentunya nasionalisme menjadi tantangan tersendiri bagi sejarah perkembangan bangsa Indonesia. Nasionalisme merupakan satu paham yang menciptakan dan mempertahankan kedaulatan sebuah negara dengan mewujudkan satu konsep identitas bersama untuk sekelompok manusia. Para nasionalis menganggap negara adalah berdasarkan beberapa "kebenaran politik" (political legitimancy). Bersumber dari teori romantisme yaitu "identitas budaya", debat liberalisme yang menganggap kebenaran politik adalah bersumber dari kehendak rakyat, atau atau gabungan kedua teori itu.

Menurut Kamus Besar
Bahasa Indonesia Nasionalisme merupakan paham untuk mencintai bangsa dan negara sendiri. Kesadaran keanggotaan dalam suatu bangsa yang secara potensial atau aktual bersama-sama mencapai, mempertahankan, dan mengabdikan identitas, integritas, kemakmuran, dan kekuatan bangsa itu serta semangat kebangsaan. (Abdullah 2001:47) mengatakan bahwa "nasionalisme adalah cita-cita yang ingin memberi batas negara" kita yang sebangsa" dengan mereka bangsa lain, anatara kita" negara kita" dan negara mereka.

Ikatan nasionalisme tumbuh ditengah masyarakat saat pola pikirnya mulai merosot. Ikatan ini terjadi saat manusia mulai hidup bersama dalam suatu wilayah tertentu dan tidak beranjak dari situ. Saat itu, naluri mempertahankan diri sangat berperan dan mendorong mereka untuk mempertahankan negerinya, tempatnya hidup dan menggantungkan diri. Faktor politik pun menjadi hal yang mempengaruhi terbentuknya jiwa nasionalisme seseorang, hal tersebut dikarenakan kurangnya kepercayaan terhadap halhal yang dianggap tidak satu tujuan, banyak yang menduga sebagai 
pencerminan dari lunturnya nilai-nilai nasionalisme seperti semangat nasionalisme, justru semangat persatuan, gotong royong, menjadi ciri negara Indonesia. nilai sosial dan lain-lain tanpa Namun pada saat ini, membeda-bedakan suku agama ras derasnya arus globalisasi menyebabkan terkikisnya nilai-nilai kebangsaan. Anak-anak lebih bangga dengan budaya asing daripada budaya bangsanya sendiri. Hal ini dibuktikan dengan adanya rasa bangga yang lebih pada diri anak manakala menggunakan produk luar negeri, dibandingkan jika menggunakan produk bangsaya sendiri. Keadaan yang seperti ini perlu ditanamkan nilai-nilai nasionalisme pada masyarakat khususnya masyarakat pedalaman melalui pelestarian nilai-nilai adat istiadat sebagai kearifan lokal khususnya yang mengandung nilainilai kebangsaan atau sering dikenal dengan nasionalisme.

Berdasarkan pengamatan peneliti, Masyarakat di Desa Mapan Jaya Kecamatan Kayan Hulu Kabupaten Sintang masih melaksanakan salah satu tradisi turun temurun yang disebut upacara adat perkawinan suku Dayak Kebahan. Pada upacara adat perkawinan sebagai kearifan lokal ini terdapat (2007:2) Kearifan lokal atau sering disebut local wisdom dapat dipahami sebagai usaha manusia dengan menggunakan akal budinya (kognisi) untuk bertindak dan bersikap terhadap sesuatu, objek, atau peristiwa yang terjadi dalam ruang tertentu. Sebagai sebuah istilah wisdom sering diartikan sebagai "kearifan/kebijaksanaan". Lokal secara spesifik menunjuk pada ruang interaksi terbatas dengan sistem nilai yang terbatas pula.

Atas dasar kenyataan itu, maka perlu pengkajian ilmiah terkait nilai-nilai kearifan lokal pada upacara adat perkawinan suku Dayak Kebahan dalam kontekstual nasionalisme di Desa Mapan Jaya Kecamatan Kayan Hulu Kabupaten Sintang. Pemikiran ini dapat di tindaklanjuti melalui pembangunan karakter berbasis nilai-nilai budaya daerah. Tujuannya adalah untuk menemukan kembali nilai-nilai kearifan lokal perkawinan adat sebagai sumber daya untuk 
menumbuhkan nasionalisme bangsa Indonesia. Hal ini diharapkan dapat menjadi sumber inspirasi, agar lebih mengutamakan kepentingan rakyat, bangsa dan negara.

Melalui pendekatan fenomenologis diharapkan dapat menemukan beberapa masalah yang dihadapi sehingga nasionalisme dalam kearifan lokal perkawinan adat di Desa Mapan Jaya Kecamatan Kayan Hulu Kabupaten Sintang terbentuk sesuai hakekat dan tujuannya, sebab pendekatan fenomenologis merupakan tradisi penelitian kualitatif yang berakar pada filosofi dan psikologi, dan berfokus pada pengalaman hidup manusia. Pendekatan fenomenologi hampir serupa dengan pendekatan hermeneustics yang menggunakan pengalaman hidup sebagaialat untuk memahami secara lebih baik tentang sosial budaya, politik atau konteks sejarah dimana pengalaman itu terjadi.

Berdasarkan pemamaparan di atas, maka penulis mengkaji secara lebih detil dalam bentuk penelitian yang berjudul "Nasionalisme dalam Kearifan Lokal pada Upacara Perkawinan Adat Suku
Dayak Kebahan di Desa Mapan Jaya". Tujuan yang hendak dicapai adalah menemukan: 1) nilai-nilai nasionalisme pada uapacara perkawinan adat suku Dayak Kebahan di Desa Mapan Jaya, 2) pelaksanaan upacara perkawinan adat Suku Dayak Kebahan di Desa Mapan Jaya masih dilaksanakan oleh sebagian masyarakat, dan 3) upaya yang dilakukan untuk melestarikan kearifan lokal perkawinan adat Dayak Kebahan di Desa Mapan Jaya.

\section{B. Metode}

Dalam penelitian ini penulis mengunakan metode penelitian kulaitatif deskriptif. Menurut Nawawi ( 2012:67) metode deskriptif dapat diartikan sebagai prosedur pemecahan masalah yang diselidiki dengan menggambarkan atau melukiskan keadaan subjek atau obyek penelitian (sesorang, lembaga, masyarakat dan lain-lain) pada saat sekarang berdasarkan fakta-fakta yang tampak, atau sebagaimana adanya. Penelitian deskriftif merupakan metode penelitian yang berusaha menggambarkan dan menginterprestasi objek sesuai 
dengan apa adanya (Sukardi, 2009:157). Berdasarkan pendapat para ahli penelitian deskriptif merupakan penelitian yang dapat menggambarkan melukiskan subjek atau obyek serta fakta-fakta dalam penelitian.

Bentuk penelitian yang digunakan dalam penelitian ini adalah penelitian fenomenologis. Fenomenologi merupakan sesuatu yang dianggap real atau nyata hanya terlihat secara spontanitas, kemudian diyakini sebagai kenyataan yang ada diluar diri manusia. Menurut Creswell (2017:18) fenomenologi merupakan rancangan penelitian yang berasal dari filsafat dan psikologi dimana peneliti mendeskripsikan pengalaman kehidupan manusia tentang suatu fenomena tertentu seperti yang dijelaskan oleh para partisipan. Sumber data atau informan yang dimaksud yaitu, kepala desa, kepala adat, Temengung, kepala dusun, ketua BPD, RT, dan masyarakat. Sumber data diperoleh juga dapat diperoleh dari masyarakat yang mengalami perkawinan adat itu sendiri dan orang-orang yang sangat mengerti tentang perkawinan adat yang ada di Desa Mapan Jaya.

Teknik dan alat pengumpulan data yang digunakan yakni teknik komunikasi langsung dengan panduan wawancara dan lembar observasi serta eknik studi dokumentasi yang dilakukan dengan katagorisasi dan klasifikasi bahanbahan tertulis yang berhubungan dengan masalah penelitian, baik dari sumber dokumen maupun buku-buku koran majalah dan lain-lain (Nawawi 2012: 101).

Analisis data telah mulai sejak merumuskan dan menjelaskan masalah, sebelum terjun kelapangan, dan berlangsung terus sampai penulisan hasil penelitian yaitu analisis sebelum ke lapangan, analisis selama di lapangan dan analisis data setelah dilapangan (Sugiyono, 2013 : 245). Analisis data selama dilapangan dilakukan dengan menggunakan teknik analisis data interaktif model Milles dan Hubberman.

\section{Pembahasan Dan Hasil}

Dari penelitian yang telah dilaksanakan tentang Nasionalisme dalam Kearifan Lokal pada Upacara Perkawinan Adat Suku Dayak 
Kebahan di Desa Mapan Jaya ini ditemukan beberapa hal, antara lain sebagai berikut:

\section{Nilai-Nilai Nasionalisme Pada Uapacara Perkawinan Adat Suku Dayak Kebahan di Desa Mapan Jaya.}

Di beberapa daerah nilainilai dalam perkawinan adat sudah mulai memudar karena kurangnya partisipasi masyarakat terhadap budaya itu sendiri dan perkembangan era dimana pernikahan adat tak disahkan oleh negara sedangkan yang diakui secara hukum dalah pernikahan berdasarkan ketentuan hukum negara, misalnya secara resmi berdasarkan UU Perkawinan. Padahal sebagai salah satu kearifan lokal adat istiadat harus tetap dilestarikan sebagai nilai luhur. Nilai merupakan sesuatu yang berharga yang terjadi di dalam kehidupan serta lingkungan yang ada (Syahruri 2013:53). Dengan memiliki sebuah nilai, berarti kehidupan akan lebih bermakna di mata orang lain. Nilainilai yang terkandung di dalam perkawinan adat yaitu bagaimana berharganya suatu perkawinan secara adat seperti halnya telah dilakukan oleh nenek moyang jaman dahulu.
Tidak ada salahnya mengikuti perkembangan jaman namun budaya sendiri yang sangat berharga, jangan sampai dilupakan, bagaimana mungkin kelestarian sebuah budaya perkawinan adat ini dapat terjaga apabila setiap masyarakat tidak memiliki kesadaran di masingmasing individu. Hilangnya budaya yang ada, maka ciri khas dari setiap masing-masing daerah pun akan ikut menghilang.

Secara umum banyak nilai yang terkandung didalam upacara perkawinan adat suku Dayak Kebahan di Desa Mapan Jaya, misalnya nilai nasionalisme yang mendukung perkembangan stabilitas nasional. Nilai-nilai nasionalisme dalam kearifan lokal pada perkawinan adat di Desa Mapan Jaya yaitu: (1) pelestarian tradisi, (2) melanjutkan sejarah suku, (3) mempererat dan memperluas hubungan keluarga, memperbanyak jumlah angggota suku, (5) nilai kebersamaan, (6) saling tolong menolong dalam melaksanakan upacara perkawinan adat, (7) rela berkorban dalam memberi. Di samping itu, Sinamo (2012:11) mengemukakan bahwa 
nasionalisme merupakan paham kebangsaan yang timbul karena adanya persamaan nasib dan sejarah, serta kepentingan untuk hidup bersama sebagai suatu bangsa yang merdeka, bersatu dan berdaulat. Selanjutnya ia mengatakan bahwa nasionalisme dalam kearifan lokal yaitu kepedulian terhadap budaya yang dimiliki di lingkungan sendiri. Namun pada kenyataannya, banyak masyarakat yang belum memahami pentingnya rasa Nasionalisme dalam kearifan lokal sebagai bentuk menjaga kelestarian budaya dari setiap masing-masing daerah dalam hal ini khususnya pada perkawinan adat di Desa Mapan jaya.

Bagi hukum adat perkawinan adalah perbuatanperbuatan yang tidak hanya bersifat keduniaan, melainkan juga bersifat kebatinan atau keagamaan (Syahuri, 2013: 64). Sehingga dapat disimpulkan, perkawinan adalah kepentingan keluarga dan masyarakat baik masyarakat sedesa maupun masyarakat adat. Pada umumnya suatu perkawinan adat didahului dengan pertunangan. Pertunangan adalah hubungan hukum yang dilakukan antara orang tua pihak laki-laki dengan orang tua pihak perempuan untuk maksud mengikat tali perkawinan anak-anak mereka dengan jalan peminangan (Syahuri, 2013: 64).

Hukum adat di Indonesia itu sendiri pada umumnya menjelaskan bahwa perkawinan bukan saja berarti sebagai perikatan perdata, tetapi juga merupakan perikatan adat dan sekaligus merupakan perikatan kekerabatan dan ketetanggaan. Jadi terjadinya suatu ikatan perkawinan bukan semata-mata membawa akibat terhadap hubungan keperdataan, seperti hak dan kewajiban suamiistri, harta bersama, kedudukan anak, hak dan kewajiban orang tua, tetapi juga menyangkut hubungan adat istiadat kewarisan, kekeluargaan, kekerabatan dan ketetanggaan serta menyangkut upacara-upacara adat dan keagamaan.

\section{Pelaksanaan}

Upacara

Perkawinan Adat Suku Dayak Kebahan Di Desa Mapan Jaya.

Saat ini walaupun zaman sudah modern tetapi di Desa Mapan Jaya masih ada sebagian masyarakat yang melaksanakan perkawinan adat disamping perkawinan yang disahkan secara negara. Sebagian 
besar penduduknya merupakan Suku Dayak, dan sebagian Kecil Suku Melayu. Pemeluk Agama yang terbesar adalah Kristen dan sebagian kecil ada Agama Islam. Pola kehidupan masyarakat sudah mengarah pada jaman modern, namun tak lepas dari adat istiadat yang turun temurun dari nenek moyang. Adat istiadat ini masih dipertahankan hingga kini walaupun banyak pengaruh terutama dari derasnya arus informasi yang di dapat dari televisi maupun pergaulan masyarakat sehari-hari ditambah lagi dengan letak Desa Mapan Jaya yang jauh dari ibu kota Kabupaten.

Upacara perkawinan dalam arti "perikatan adat" ialah perkawinan yang mempunyai akibat hukum terhadap hukum adat yang berlaku dalam masyarakat bersangkutan (Syahruri, 2013:50). Setelah terjadinya ikatan perkawinan maka timbul hak-hak dan kewajibankewajiban orang tua (termasuk anggota keluarga atau kerabat) menurut hukum adat setempat yaitu dalam pelaksanaan upacara adat dan selanjutnya dalam peran serta membina dan memelihara kerukunan, keutuhan dan kelanggengan dari kehidupan anakanak mereka yang terikat dalam perkawinan. Sejauh mana ikatan perkawinan itu membawa akibat hukum dalam perikatan adat, seperti tentang kedudukan suami dan kedudukan istri, begitu pula tentang kedudukan anak dan pengangkatan anak, kedudukan anak tertua, anak asuh, anak adat dan lain-lain serta harta perkawinan yaitu harta yang timbul akibat terjadinya perkawinan tergantung pada bentuk dan sistem perkawinan adat setempat.

Perkawinan pada Suku Dayak Kebahan biasanya dilaksanakan setelah pertunangan dengan jarak sesuai kesepakatan kedua belah pihak dan disetujui oleh pemangku adat. Perkawinan adat harus ada Tumenggung adat yang mengatur dan membuat surat pernikahan dalam artian wajib disaksikan oleh Tumenggung adat.

Proses atau tata cara pelaksanaan perkawinan dimulai dengan acara yakni satu hari sebelum dilangsungkannya upacara perkawinan, rombongan dari pihak laki-laki harus sudah datang ketempat calon istri dan dalam bahasa Dayak Kebahan disebut 
"nyurong bebini". Dalam nyurong bebini ini biasanya banyak orang dari rombongan yang datang bahkan satu kampung biasanya ikut semua. Dalam pelaksanaannya kedua belah pihak mempelai saling melengkapi, termasuk dalam hal membeli perlengkapan makan minum dan keperluan lainya. Lamanya acara berlangsung 3 hari 2 malam, mulai dari rombongan laki-laki datang sampai mereka pulang.

Hari sebelum kedatangan rombongan laki-laki, pihak perempuan menyiapkan pagar ompong yang dibuat seperti gapura dari daun kelapa dan dihiasi. Disisi kanan dan kiri juga dihiasi dan diberi botol tuak (semacam minuman beralkohol rendah terbuat dari beras ketan) digantung setiap sisi. Bagian bawah disimpan piring berisi telur ayam, beras kuning dan baja/besi. Bagian tengah diberi penghalang berupa batang pisang atau tebu yang dimaksud agar rombongan dari pihak laki-laki tidak bisa masuk sebelum ada persetujuan dari pihak wanita. Bagian atas ompong tersebut dipasng kain yang membentuk tanda (+) kain sebanyak 4 lembar dan diatas kain dipasang payung.
Setelah saatnya tiba, pihak laki-laki yang nyurong datang. Ada beberapa utusan dari pihak wanita yang jemput untuk memberitahu kepada pihak wanita kalau mereka akan datang. Setiap satu rombongan dari pihak laki-laki datang maka akan dibunyikan gong. Setelah selesai semua pihak laki-laki telah datang berkumpul maka dilanjutkan dengan acara menani / beduda (dari pihak perempuan diwakili perempuan dan dari pihak laki-laki diwakili oleh laki-laki). Selanjutnya acara dilajutkan dengan pemotongan pagar ompong dengan terlebih dahulu tetua dari pihak laki-laki menanyakan apakah sudah bisa dipotong atau tidak “...sida mali kami notak pagar ompong tok...”. Kemudian pihak perempuan diwakili tetua menjawab tidak boleh “...mali...." dan kata-kata itu diulang sebanyak 6 kali. Setelah pertanyaan ke tujuh baru dijawab boleh, maka pagar ompong bisa dipotong, setelah itu dilanjutkan dengan prosesi menginjak telur ayam dan ditaburi beras kuning, kemudian diperbolehkan masuk dan salamsalaman sambil dibagikan minuman tuak. 
Adapun adat perkawinan ini, sang pria harus memberikan kasur dan kelambu dahulu kepada calon istri kalau tidak ada maka dapat diganti dengan membayar uang RP. 480.000;. Selain itu ada juga adat batang tubuh atau adat kecantikan harus lengkap sesuai dengan keperluan wanita pada umumnya, seperti sepasang baju tidur, selimut, bantal, alat-alat mandi, handuk, kain, kosmetik, sisir, cermin, ikat rambut, jepitan rambut, celana, baju dan lainlain. Disamping itu ada sejumlah adat lainnya yang diatur kemudian sesuai kesepakatan adat yang disesuaikan dengan kesanggupan pria.

\section{Upaya Yang Dilakukan Untuk} Melestarikan Kearifan Lokal Perkawinan Adat Dayak Kebahan di Desa Mapan Jaya. Istilah kearifan lokal tidak hanya mengandung makna bahwa kearifan tersebut tumbuh dari pemecahan masalah yang bersifat lokal, tetapi kesahihannya pun terbatas pada lingkungan di mana dia tumbuh dan berkembang (Suja dalam Mardawani \& Lusiana, 2017). Pendapat tersebut mengisyaratkan bahwa kearifan lokal dapat ditemukan dari mana saja nilai itu tumbuh dan berkembang. Dalam mewujudkan cita-cita nasional untuk memajukan kebudayaan daerah maka perlu adanya upaya pelestarian dari adat dan budaya yang ada, bukan hanya peran dari sebagian masyarakat saja, bukan hanya tugas pengurus adat ataupun kepala desa, tetapi harus adanya kebersamaan dan kerjasama dari semua pihak masyarakat tanpa terkecuali. Hal ini sebagai upaya untuk tetap menjaga kebudayaan yang ada agar adat istiadat yang ada tidak menghilang dan selalu dilaksanakan sampai generasi berkutnya.

Berdasarkan hasil penelitian di lapangan, peneliti menemukan masih ada beberapa warga setempat yang masih memiliki kesadaran akan pentingnya perkawinan adat di Desa Mapan Jaya dan masih tetap berupaya untuk menjaga dan melestarikan budaya tersebut, meskipun hanya beberapa tetapi setidaknya masih ada masyarakat yang mengetahui dan peduli terhadap lingkungannya khususnya mengenai perkawinan secara adat itu sendiri. Sebagai upaya mewujudkan pelestarian dari adat dan budaya 
yang ada, bukan hanya peran dari sebagian masyarakat saja, bukan hanya tugas pengurus adat ataupun kepala desa, tetapi harus adanya kebersamaan dan kerjasama dari semua pihak masyarakat tanpa terkecuali.

Upaya yang dilakukan tidak terlepas dari motivasi yang ada pada masyarakat. Dimyati (2013 : 80) menyatakan motivasi dipandang sebagai dorongan mental yang menggerakkan dan mengarahkan perilaku manusia. Hal ini berarti tergantung pada keinginan dan nilainilai budaya dari masyarakat yang bersangkutan tetapi segala sesuatunya tidak boleh bertentangan dengan kepentingan umum, Pancasila dan Undang-undang Dasar 1945. Sehingga perkawinan dalam arti "perikatan adat" walaupun dilangsungkan antar adat yang berbeda tidak akan seberat penyelesaiannya daripada berlangsungnya perkawinan yang bersifat antar agama, ini dikarenakan perbedaan adat hanya menyangkut perbedaan masyarakat bukan perbedaan perkawinan (Hadikusuma, 2007: 8-10)
Menurut Ridwan (2007:2)

dapat dipahami sebagai usaha manusia dengan menggunakan akal budinya (kognisi) untuk bertindak dan bersikap terhadap sesuatu, objek, atau peristiwa yang terjadi dalam ruang tertentu. Pengertian tersebut, disusun secara etimologi, di mana wisdom dipahami sebagai kemampuan seseorang dalam menggunakan akal pikirannya dalam bertindak atau bersikap sebagai hasil penilaian terhadap sesuatu, objek, atau peristiwa yang terjadi. Sebagai sebuah istilah wisdom sering diartikan sebagai "kearifan/kebijaksanaan". Lokal secara spesifik menunjuk pada ruang interaksi terbatas dengan sistem nilai yang terbatas pula. Sebagai ruang interaksi yang sudah didesain sedemikian rupa yang di dalamnya melibatkan suatu pola-pola hubungan antara manusia dengan manusia atau manusia dengan lingkungan fisiknya. Upaya melestarikan kearifan lokal perkawinan adat Dayak Kebahan di Desa Mapan Jaya pada era sekarang ini seperti yang dilakukan di atas perlu mendapat perhatian dari semua pihak, hal ini sejalan dengan apa yang dikemukan 
oleh Mardawani dan Lusiana (2018), yang menyatakan bahwa "upaya pembentukan karakter dimasyarakat lokal perlu dilakukan dengan pendekatan kearifan lokal khususnya pembentukan karakter generasi muda"

\section{Simpulan}

Melalui Berdasarkan hasil penelitian dan pembahasan yang telah dikemukakan oleh peneliti yang bersumber dari hasil observasi, wawancara dan dokumentasi mengenai Naionalisme dalam Kearifan Lokal pada Perkawinan Adat Desa Mapan Jaya Kecamatan Kayan Hulu Kabupaten Sintang, maka dapat disimpulkan sebagai berikut:

1. Nilai-nilai nasionalisme yang terkandung di dalam perkawinan adat Suku Dayak Kebahan yaitu nilai nasionalisme yang mendukung perkembangan stabilitas nasional. Nilai-nilai nasionalisme dalam kearifan lokal pada perkawinan adat di Desa Mapan Jaya yaitu: (1) pelestarian tradisi, (2) melanjutkan sejarah suku, (3) mempererat dan memperluas hubungan keluarga, (4) memperbanyak jumlah angggota suku, (5) nilai kebersamaan, (6) saling tolong menolong dalam melaksanakan upacara perkawinan adat, (7) rela berkorban dalam memberi.

2. Saat ini walaupun zaman sudah modern tetapi di Desa Mapan Jaya masih ada sebagian masyarakat yang melaksanakan perkawinan adat disamping perkawinan yang disahkan secara negara. Adat istiadat ini masih dipertahankan hingga kini walaupun banyak pengaruh terutama dari derasnya arus informasi yang di dapat dari televisi maupun pergaulan masyarakat sehari-hari ditambah lagi dengan letak Desa Mapan Jaya yang jauh dari ibu kota Kabupaten. Perkawinan pada Suku Dayak Kebahan biasanya dilaksanakan setelah pertunangan dengan jarak sesuai kesepakatan kedua belah pihak dan disetujui oleh pemangku adat. Perkawinan adat harus ada Tumenggung adat yang mengatur dan membuat surat pernikahan dalam artian wajib disaksikan oleh Tumenggung adat. Proses atau tata cara pelaksanaan perkawinan dimulai dengan acara yakni satu hari 
sebelum dilangsungkannya upacara perkawinan, rombongan dari pihak laki-laki harus sudah datang ketempat calon istri dan dalam bahasa Dayak Kebahan disebut "nyurong bebini".

3. Dalam mewujudkan cita-cita nasional untuk memajukan kebudayaan daerah maka perlu adanya upaya pelestarian dari adat dan budaya yang ada, bukan hanya peran dari sebagian masyarakat saja, bukan hanya tugas pengurus adat ataupun kepala desa, tetapi harus adanya kebersamaan dan kerjasama dari semua pihak masyarakat tanpa terkecuali. Hal ini sebagai upaya untuk tetap menjaga kebudayaan yang ada agar adat istiadat yang ada tidak menghilang dan selalu dilaksanakan sampai generasi berkutnya. Sebagai upaya mewujudkan pelestarian dari adat dan budaya yang ada, bukan hanya peran dari sebagian masyarakat saja, bukan hanya tugas pengurus adat ataupun kepala desa, tetapi harus adanya kebersamaan dan kerjasama dari semua pihak masyarakat tanpa terkecuali.

\section{Daftar Pustaka}

Abdullah, $\quad$ Taufik. 2001. Nasionalisme dan Sejarah. Bandung: Satya Historika.

Akdon, Riduwan . 2007. Rumus dan Data Dalam Analisis Statistika.Bandung: Alfabeta.

Dimyati \& Mudjiono. 2013. Belajar Dan Pembelajaran. Jakarta: Rineka Cipta.

Mardawani \& Lusiana. 2017. Pengembangan Karakter Kebangsaan Berbasis Kearifan Lokal Sebagai Alternatif Pendidikan Informal di Kabupaten Sintang. Jurnal Pekan. (Online), Vol 2 Nomor 2, (http://jurnal.stkippersada.ac.id/j urnal/index.php/PEKAN/issue/vi ew/28, diakses 16 Maret 2019).

2018. Peran

Mahasiswa Dalam Upaya Membentuk Generasi Muda Berkarakter Melalui Pendekatan Humanis Berbasis Kearifan Lokal Suku Dayak Di Desa Telaga II. Jurnal Pekan. (Online), Vol 3 Nomor 1, (http:// http://jurnal.stkippersada.ac.id/ju rnal/index.php/PEKAN/issue/vie w/29, diakses 3 Maret 2019).

Moleong, Lexy J. 2012. Metodologi Penelitian Kualitatif. Bandung: Remaja Rosdakarya.

Nawawi, Hadari. 2012. Metode Penelitian Bidang Sosial. Yogyakarta: Gadjah Mada University Press.

Sinamo, Nomensen. 2012. Pendidikan Kewarganegaraan

ISSN: 2540 - 8038 
Jurnal PEKAN Vol. 4 No. 1 Edisi April 2019 Mardawani,Muisan.J,Nasionalisme...88

untuk PerguruanTinggi.Jakarta:

Permata Aksara.

Sukardi.2009. Metodologi Penelitian Pendidikan. Jakarta: Bumi Aksara.

Sugiyono. 2013. Metode Penelitian Kuantitatif Kualitatif dan $R \& D$. Bandung: Alfabeta.

Syahuri, Taufiqurrohman. 2013. Legislasi Hukum Perkawinan di Indonesia. Jakarta: Kencana.

Undang-Undang No 1 Tahun 1974 Tentang Perkawinan, Tambahan Lembaran Negara Republik Indonesia Nomor 1. 